\title{
The iTaukei Chief: Value and Alterity in Verata
}

\section{Matti Eräsaari}

\section{(2) OpenEdition}

\section{Journals}

Electronic version

URL: http://journals.openedition.org/jso/7407

DOI: $10.4000 /$ jso.7407

ISSN: $1760-7256$

\section{Publisher}

Société des océanistes

\section{Printed version}

Date of publication: 15 December 2015

Number of pages: 239-254

ISBN: 978-2-85430-126-7

ISSN: 0300-953x

\section{Electronic reference}

Matti Eräsaari, «The iTaukei Chief: Value and Alterity in Verata », Journal de la Société des Océanistes [Online], 141 | juillet-décembre 2015, Online since 15 December 2018, connection on 20 April 2019. URL : http://journals.openedition.org/jso/7407 ; DOI : 10.4000/jso.7407 


\title{
The iTaukei Chief: Value and Alterity in Verata
}

by

\author{
Matti Eräsaari*
}

\begin{abstract}
Over the course of the last century and a half, the structural and political underpinnings of Fijian chieftaincy have changed in significant ways and is no longer best represented by the union of the stranger-chief and local lineage. According to what must be the most widelyaccepted origin mythology in present-day Fiji, the first Fijians arrived from Tanganyika, Africa. Emphasising the shared origins of all indigenous Fijians, this mythology denies the internal differentiation between autochthones and strangers that is often highlighted as a key constituent in Fijian political organization. In this ethnographic tradition, it is the "synthetic" combination offoreign charisma and autochthonous legitimation that holds up chieftaincy. Colonial-era Native Legislation reveals us a similar denial of the dichotomy in material and linguistic terms, overriding the distinction between the land-owning autochthones and the landless strangers, respectively designated as the "owners" or "hosts" (taukei) and "strangers" or "guests" (vulagi). This article considers the 2010 governmental decision to replace the words "Fijian" or "native Fijian" with the word iTaukei in official English-language use as merely the most recent example of a development that has been in the making for a considerable while.
\end{abstract}

KEYwORDs: value, origin, alterity, autochthony, tabua

\section{RÉSUMÉ}

Au cours du dernier siècle et demi, la structure et les soubassements politiques du système de chefferie de Fidji ont changé de manière significative, et leur meilleure représentation n'est plus l'union de l'étranger-chef avec le lignage local. Selon ce qui est sans doute le mythe des origines le plus largement accepté à Fidji aujourd'hui, les premiers Fidjéens arrivèrent de Tanganyika, en Afrique. Mettant l'accent sur les origines partagées de tous les Fidjéens, ce mythe nie la distinction interne entre autochtones et étrangers - distinction souvent présentée comme un constituant clef de l'organisation politique de Fidji. Dans cette tradition, c'est la combinaison "synthétique " entre le charisme étranger et la légitimité autochtone qui définit la chefferie. La législation autochtone de l'ère coloniale nie également la dichotomie matérielle et linguistique entre les propriétaires fonciers autochtones et les étrangers sans terre, respectivement désignés comme "propriétaires" (taukei) et "hôtes" (vulagi). Cet article se penche sur la décision gouvernementale de 2010 de remplacer les mots "Fidjian" ou "Native Fidjian" par le mot iTaukei en anglais officiel - une décision qui n'est que l'exemple le plus récent d'un développement qui est en cours depuis longtemps.

MoTs-CLÉs: valeur, origine, altérité, autochthonie, tabua
In 2010 the Government of Fiji passed a decree which replaced the English words "Fijian", "indigenous" and "indigenous Fijian" with the Fijian word "iTaukei" in all the Englishlanguage laws, official documents and names of Government agencies referring to "the original and native settlers of Fiji" (Government of Fiji 2010). Consequently, the Ministry of Indigenous Affairs became the Ministry of iTaukei Affairs, the Fijian Affairs Act became the iTaukei Affairs Act, and so forth ${ }^{1}$. In the simplest of terms, what happened here was that the government used its

* Newton International Fellow, Social Anthropology, University of Manchester, matti.erasaari@helsinki.fi

1. Since this article looks into changes that have occurred in the meaning of the word taukei, I will try to avoid unnecessary confusion by sticking with the old system, using the expressions "indigenous" or "indigenous Fijian" for indigenous Fijian 
authority to establish an endonym in place of the misleading "Fijian", a term which can be used both in reference to the indigenous population and to Fijian nationals.

Everyone familiar with Fiji's recent history of coups and the role ethnicity has played in the coups understands that the name change works in two ways: it both sets apart the group designated as taukei ${ }^{2}$ as a distinct category, but it can also be seen as an attempt at broadening the gloss of the word "Fijian" - "freeing" the noun denoting Fijian nationality to usage that is devoid of ethnic connotations, as it were. Whether the first should have been attempted in the first place, and whether the second is possible just by a governmental decision, are both questions that this article addresses only indirectly. What I want to draw attention to, instead, is what a valueladen choice this is, and what are the structural implications of such a choice.

The word taukei has for a long time been defined as one half of a conceptual pair, serving as counter-notion to that of vulagi, the "guest" or "stranger". The significance of foreign origin in indigenous Fijian value systems has been a constant theme in the ethnography of Fiji; this has been elaborated with regard to political power and exchange value in a highly persuasive manner by Marshall Sahlins in particular (see e.g. Sahlins, 1985, 1994, and also 2013). In this conceptual pairing, taukei does indeed stand for "the original settlers", as clarified by the Government circular letter cited above, but it also stands for the notions of "owner" and "host". Together, the conceptual pair can be taken to exemplify how certain values can be "preserved in the very fabric of language", as E. P. Thompson (1970 [1968]: 54) once phrased it. Though Thompson speaks of the moral values of the English crowd rather than the binary semantic values of Fijian symbolic order that I evoke here, I want to emphasise that the two are, in this instance at least, inseparable. Linguistic value is also, as Saussure (1993 [1983]: 113) already reminded us, a fundamentally social construction that relies on the general acceptance of the community of speakers.

Unaisi Nabobo-Baba (2006) gives a fair account of the connotations expressed through the taukei-vulagi dichotomy in the district of Vugalei, south-eastern Viti Levu:

"The Vugalei Fijian see the world in terms of a clear dichotomy between taukei - people who are of the land, own the land and therefore look after the land - and vulagi (visitors). Visitors are seen as not belonging, and therefore not feeling responsibility for the land, resources and all else that exists within it [...] those who are taukei to a vanua ("land") should always have the best interests of their vanua at heart, especially if they are brought up well. » (NaboboBaba, 2006: 44-45)

However, it is not the different interests of the owner and the visitor that come out most strongly in Nabobo-Baba's writing, but rather the implications of the moral higher ground occupied by the taukei. In the words of one of her interlocutors: "If I was a vulagi woman, I could not speak out freely" (Nabobo-Baba, 2006: 45). In an examination of texts forwarded during the public hearings organised for the review of the 1990 constitution, Robert Norton (2000) discusses a range of different takes on the taukeil ulagi dichotomy. These show how the ideology discussed by Nabobo-Baba can be harnessed into national-level political usage, a rhetorical move sometimes labelled "taukeism". Here are some examples:

" "The Fijians regard themselves as the owner of Fiji in the same way the owner of a house protects his interests in his house," and they do not respond favorably to tenants "who demand equal rights with the owner" as the issue was phrased by the Viti Civil Servants' Association. » (Norton, 2000: 103)

The svT party's petition phrased the issue even more pointedly:

"The Taukei are normally at the forefront in decision making. The vulagi are allowed to participate [...] but they must not be domineering or forceful. [...] Whilst they are welcome to stay and enjoy the fruits of their labour, [...] they need to be reminded time and time again of this fact. [...] The taukei and vulagi concept, host/guest relationship, continues to be challenged and upset by [...] the human rights concept in which all are considered equal. " (Norton, 2000: 98; see also Ravuvu, 1991)

And so it goes on, all the way to the Methodist Church's call "to ensure the absolute control over this nation by the i Taukei" (Norton, 2000: 100).

Similar rhetoric is very common in the Tailevu Province where I conducted research in 2007-2008, and judging by conversations held with visitors from other parts of Fiji, not uncommon elsewhere in indigenous Fiji either. Most typically applied to interethnic relations, the point typically remains the same: "they are the guests, they ought to know their place».

This is radically different from a Fiji that once

people and culture. In the pre-2010 state nomenclature, institutions referring to indigenous Fiji often used simply "Fijian": I prefer to reserve this label to people and phenomena of or from the Republic of Fiji, regardless of ethnic background.

2. The spelling preferred in the names of official state institutions simply places the particle $i$ before the root word taukei. In such instances the particle connotes "the person or thing acted on" (Capell 2003 [1941]: 73), as in "the ministry acting on iTaukei affairs". 
allowed A. M. Hocart to gloss vulagi both as "guest" and as "heavenly god" (cited in Sahlins, 1985: 75) rather than a mere "visitor". Indeed, it is the liberal and accommodating view on "visitors" that makes the contrast between the "past" and "present" guests particularly pronounced, such as the one expressed by Ratu Nacula Jo, who would rather portray the taukei

" as the gracious host who is mindful of the interests of other communities [...] the honoured guests. " (Norton, 2000: 98)

For such a view brings to the fore with marked finality exactly how far the current usage is from the idea of chieftainship based on alterity: stranger-kings, sacred nephews or ruthless usurpers can hardly feed off the kind benevolence of their gracious hosts.

This article addresses the theme of Fijian chieftainship from the viewpoint of the categories of guest and host, presenting first the socialstructural argument on an abstract, "as if" basis and then an ethnographic case from the particular location that I am most familiar with, the village of Naloto in Verata, Tailevu. Although I view the ethnographic case and the historical argument as fundamentally intertwined, I want to keep the two threads apart for two reasons. First of all, the chiefdom of Verata has a unique position in the Fijian order, and the ideas of autochthony and alterity implied by the categories of stranger and guest are crucial to that position. Verata is the chiefdom that is most consistently regarded as the genealogical senior among the Fijian chiefly families, and could with relative ease be regarded either as the epitome of the alterity of chieftaincy or its opposite, the origin point par excellence (Eräsaari 2013). In other words, what applies for one region in Fiji does not necessarily apply for another. And for this reason, I want to first present the largely shared core ideas and common history that is applicable to most of Fijian ethnography, and only then the particular way in which these ideas play out in the Naloto social world.

\section{Taukei vs. vulagi: the structural argument}

In Lau Islands, Fiji, A. M. Hocart forwards the often-cited claim that Fijian chiefs "came from overseas: it is so in all countries in Fiji" (Hocart, 1929: 27). The claim agrees with an observable general pattern which is present throughout the ethnography of central-eastern Fiji, from Brewster (1922) to Hocart (1929, 1970 [1936]) and Sahlins (e.g. 1972, 1985, 1994), with the general principle also upheld by Kaplan (1995) and Toren $(1988,1994)$, to name but a few.
The argument, in a nutshell, is that particularly coastal East Fijian chiefs have been regarded as landless aristocrats who are dependent on their subjects for their material welfare, but are at the same time powerful leaders because of the alterity they incorporate. This duality is realised through the founding marriage between an apical male ancestor and his autochthonous spouse, whose offspring then make up the chiefly dynasty. Chiefly lineages, in other words, can be regarded both as strangers vis-à-vis the owners of the land due to their foreign ancestry, and as their indigenous kinsmen: "synthetic personae" who incorporate both autochthonous and foreign values. Yet it has been the foreign side that has traditionally served as the marker of chiefly charisma (Sahlins, 1994; cf. Geertz, 1983).

Hocart's interpretation of the word vulagi as "heavenly god" ( $v \bar{u}+$ lagi $)$ is inseparable from the socio-cultural underpinnings of this model of chieftainship; for him it is an expression of what Kajsa Ekholm-Friedman and Jonathan Friedman (1995) discuss as exo-sociality, the utilisation of distinctly foreign means for local ends; or what Rupert Stasch (2013) describes as "xenophilia" or the "variety of representations in which people [...] invest the culturally and ethnically different with special value" and what Marshall Sahlins discusses as "alterity" $(2012,2013)$ in reference to the socio-cultural principle of differentiation that often precedes economics in the determination of spiritual and material value. What all three clearly show is that this principle does not apply to politics alone, but can be observed in a variety of interrelated contexts, ranging from economic to semantic, moral or, according to Sahlins (2013), even nutritional value.

Hence, as Sahlins (e.g. 1994) has shown, in addition to the chiefs being strangers, so were their attendants, close allies and paraphernalia. The chiefs surrounded themselves with foreigners, wore foreign decorations made by foreign artisans, even assumed foreign titles. The value of alterity has been particularly manifest in the tabua, whale teeth that have been described as "Fijian money" by Marcel Mauss (1966: 29), "cultural currency" by Andrew Arno (2005), and as similar to money by Nicholas Thomas $(1991,1995)$. This worth, it has repeatedly been shown (for previous work on tabua see Hooper 2013: 103-106), is due to the objects' foreign origin. As a matter of fact, this was not evident merely in origin myths (see Sahlins, 1983: 72-73; Thomas, 1991: 70): 19 $9^{\text {th }}$ century sources also state that the exchange value of tabua varied in accordance to the physical signs of age displayed by the objects: the difference between the "red" and the "white" whale teeth was, according to the beachcomber William Diaper, "the same as between our shillings and sovereigns". The red teeth, Diaper informs us, "were brought 
to the Feejees by the Tongans, by whom they were first introduced" (Erskine, 1967 [1853]: 439; see also Williams, 1985 [1858]: 40-41). In a manner reminiscent of Malinowski's analysis of the kula exchange, these items then prove that not only does the objects' exchange value increase with the distance they have travelled, value may also be recorded onto the objects in marks of wear that Malinowski identified as "historic sentimentalism" (Malinowski, 1984 [1922]: 89; see also Godelier, 1999).

Yet the whale teeth do not just draw their value from the same source that also comprises the chiefs' charisma, the mythological accounts actually draw close parallels between the tabua and the chiefs. The whale teeth not only first appear in Fiji together with the foreigner-chief in the best-known myth accounting for the origin of whale teeth (Stanmore papers ca 1875-1880; Sahlins, 1983: 72-73; Thomas, 1991: 70), but also share a name with the foreigner, Tabua. In another myth, a multiply-reversed version from interior Viti Levu reported by Abramson (2013: 13-14), the sacred stranger brought in by the shark-god is a woman known as Adi Waimaro, who herself turns into a whale tooth and is stored away as a valuable. A recent issue of the Journal of the Polynesian Society (122 [2]) presents an exhaustive analysis of the material and the cosmological origins of Fijian tabua, clearly illustrating that original source of Fijian tabua is in Tonga. But Clunie's (2013) contribution in particular further illustrates that the histories of whale teeth and stranger-kings are fundamentally intertwined: that the Tongan tapua, crescentshaped objects made from ivory, were once heirlooms or "shrines" containing lineage deities and associated with first-fruits type harvest rites. Between the $15^{\text {th }}$ and the $17^{\text {th }}$ centuries,

« successive Tu'i Tonga [...] set about forging a fresh power base in Fiji, spawning hybrid lineages, becoming variously deified and disseminating tapua, which changed the face of Fijian society. " (Clunie 2013: 164-165)

The growing importance of tabua in Fiji was, from the outset, connected with the Tongan chiefly influence in Fiji.

The whale teeth, in other words, are a powerful symbol of the foreign value invested in Fijian chieftaincy. But the issue extends much further: the dichotomy of stranger-guests and autochthonous hosts is also generalizable to the wider relations between groups designated as "land" and "sea", whilst the "land" and "sea" designations in their turn also express the material conditions of land ownership - a political economic rationale, if you will. All of this has, again, been extensively reported elsewhere (for references, see below), so I will here present but the bare-bones version that makes it possible to follow my argument.

The status of "guest" marked the old-time chiefs off as a non-land-owning category: Hocart's informants told him as much in the Lau group, where " $\mathrm{t}]$ he nobles of old had no land; they had only the authority (lewa)" (Hocart, 1929: 98). But a similar pattern can be traced in Eastern Viti Levu, too: in the village of Naloto, people maintain that the chiefs of old did not own land, and though they became official land owners when the village lands were surveyed in the 1930s, theirs is but a small patch of land in comparison to the Naloto "land warriors" (bati). The same applies for the Naloto "sea people", two immigrant clans of shared ancestry from the nearby village of Ucunivanua, whose farm land lies at the edge of the village land area. Together, the sea moiety and the chiefly lineage comprise over $50 \%$ of the village population, yet own less than $10 \%$ of the village lands (see Eräsaari 2013: 18-39) In this respect, the distinction between chiefs and people is materially similar and symbolically largely overlapping with the division into land and sea people that comes to the fore on ritual occasions, when the groups denoted as "land" and "sea" (are expected to) follow a set of prescriptive rules: the sea people should provide salt water produce to the land people and abstain from eating it themselves, whilst the land people should provide pork and root crops to the sea people and abstain from eating pork, red coconut cream or plantains. For the clans designated as "sea people" (kai wai), like the foreigner-chiefs, "do not belong to the original scheme of things, never being natives of the tribe, but foreigners attached to it" as specialist groups who ply their trade "only for the chiefs" (Hocart, 1970: 108). Sea people are, as a rule, considered more proficient fishermen and are often expected to make a living from the sea rather than land, which they were only entitled to as affines or due to the benevolence of their hosts in the "original scheme of things".

A. M. Hocart illustrates the overlapping of the categories of land and sea with those of "noble" and "warrior" (bati) as they are played out on the geographical plane:

« each coast tribe stands to one or more tribes inland of them in the relation of coast and hill, or noble and mbati [bati] or tooth on edge; the "hill tribe" in its turn is "coast tribe" to one further inland, and so it goes on. This relation is called veimbatiki [veibatiki], or relation of noble and mbati. It involves certain food restrictions: thus the coast tribe may not eat fish in presence of its mbati, nor can the mbati eat pig in presence of the coast tribe; as for turtle and large fish, the coast tribe might not eat them at all, but had to send them to the mbati; if they ate it in secret, as often happened, and it was found out, they had their houses burnt down. » (Hocart, 1924: 186) 


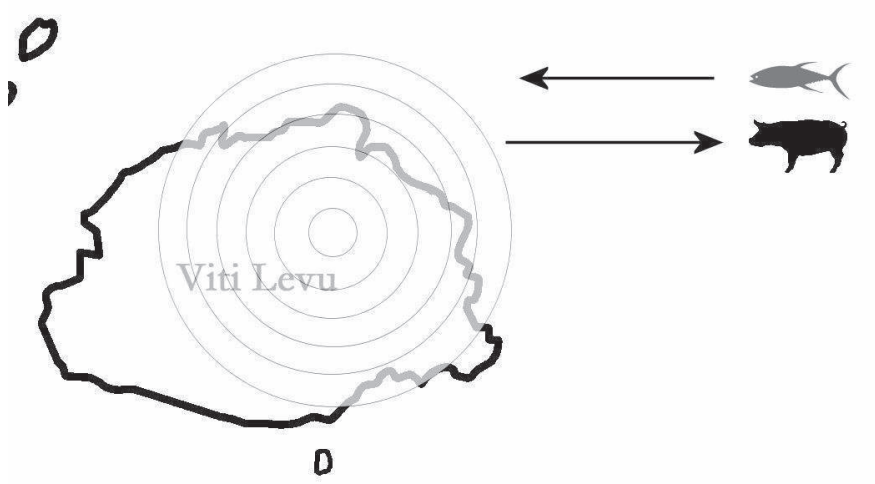

0

ceremonial obligation was to provide fish from the Wainibuka river, which they gave to the Bati, the Bati people gave pork to the Tui, until a section of the chiefly group was forced to move away from the chiefdom of Naloto and settle in what became Naloto village "probably because they ate something they should not have", I was told in the village.

Ultimately, the sea people were not just dependent on the land people for farm land, root crops and manpower: the land people also installed or "made" (buli) the chiefs in what can be seen as the structural equivalent of Hocart's (1929) famous descriptions of chiefly installations in the Lau group - in which the strangerchief symbolically dies during the ceremony in order to be reborn as a

MAP 1. - Sea encompasses land: author's depiction of Hocart 1924 (Viti Levu map from Wikimedia Commons)

What Hocart illustrates is that although based on the material conditions of land ownership on the village or corresponding local level, the same categories co-exist on the inter-village or inter-chiefdom level, where they take on a more relational character. He depicts North-Eastern Viti Levu as a series of consecutive zones, where the same group can be classified as "sea" in relation to the groups landward from it and as "land" in relation to those seaward of it; these relationships find expression in exchanges of fish and pork moving against each other, fish moving inland from the coast and pork towards the coast from inland. All this can be visualised as a relation of encompassment, where the hierarchically superior sea encompasses land on every consecutive level. Even sea people who are not considered "nobles" are easily fitted in this pattern in Hocart's model, in which they are affiliated with the chiefs; maintain their specialist role only for the chiefs (map 1).

But Hocart's explanation of the relationship between land and sea also illustrates another important characteristic of the arrangement. Though the sea denomination stands for "nobility" and chiefliness, the landspeople have privileges to counterbalance their obligations. A coast tribe who ate the bati's due, Hocart recalls, "had their houses burnt down". These are no mere formalities.

The same assumptions were also present in my fieldwork site, Naloto village, which is said to take its name from the inland polity of Naloto in Wainibuka. According to Naloto village sources, the Wainibuka polity was split into two groups in the mythical past: the Tui ("chief") people, closer to the Wainibuka river, became the chiefly group vis-à-vis the Bati people, who took residence "in the bush". The Tui people's god of the land (see also Sahlins, 1985: 73-103). This is why Hocart regarded the $19^{\text {th }}$ century divine kings as synthetic personae who, once in office, combined the gods of the land with their own stranger ancestry. "Fijian titles are in [sic] the gift of certain families, who alone can perform the rite of installation", he writes elsewhere (Hocart, 1922: 289), and from this point of view it makes sense to recall what the head of the installing clan in Naloto was keen to point out to me - that

"The sauturaga [installer/war chief] and the matanivanua [spokesman] are born into their stations, the komai [hereditary village chief] is not "

According to this model, there should be no hereditary chieftaincy in Fiji.

Thus in this east Fijian tradition the hierarchical superiority of the sea/stranger/guest denomination can only be legitimated through the dichotomic relation with its antithesis, as the installation of the foreigner-chief by the autochthonous "king makers" clearly illustrates. Even the powerful rulers of the big coastal polities required autochthonous legitimation for their rule - a point emphasised by Martha Kaplan (1995), who pointed out that the colonial-era codification of Fijian culture turned the eastern/ coastal arrangement into a model for Fijian political organisation writ large. The centralised political power of the coastal chiefs was both more convenient for administrative purposes and corresponded with the expectations of the colonial administrators. The resulting largescale inability to recognise the "land" groups' structural claims led to the rise of a powerful hereditary Fijian chiefly class: the installing groups were no longer necessary. But it is crucial to recognise the fact that in the long run, it is 
impossible to maintain one half of a dichotomy and do away with the other: the two rely on one another for definition. The strangeness of the stranger needs the autochthone or the in-group to remain strange: once the contrast disappears the distinction is void of meaning - the stranger grows unstrange, as happens in a Bernard Malamud novel (The Assistant, 1957). Hence the colonial administration's failure to recognise the structural arrangement contained in the dichotomy of land and sea led them not only to make all Fijian clans land owners in concrete terms - regardless of "land" or "sea" affiliations - they also adopted the practice of translating "native Fijian" as taukei in colonial legislation.

\section{The historical argument}

The emergence of a state-approved Fijian culture has been described and explained elsewhere (e.g. France, 1969; Kaplan, 1988; Kaplan and Kelly, 2001; Kelly, 2004), so again I will but recapitulate. What emerged from the work of a group of turn-of-the- $20^{\text {th }}$-century ethnographeradministrators was an administrator's version of Fijian culture, encoded in the Native Laws and Regulations. Almost every aspect of Fijian culture was codified in the Native Regulations: from the chiefs' obligations towards their people to the limits of their privileges; from proper window and house foundation sizes to correct religious practises, acceptable reasons for leaving one's home village; marriages, funerals, taxation values for village produce, observance of the Sunday Sabbath, monetary limits for requests from kinsmen and rules regarding stray pigs, and so forth. But, crucially, the whole construction was founded upon collective land ownership. From Lorimer Fison's (1881) tradition-defining lecture it still took almost forty years to decide upon which level of social organisation the land ownership ought to be fixed. In the end it was decided that the land-owning unit is the mataqali, although it became obvious early on that not only did patterns of land ownership vary throughout Fiji, but also the meaning of this social division varied - people were uncertain what was the difference or relation between the mataqali and the yavusa, for example (France, 1969).

In material terms, this process came to define all native Fijians as land owners. Every mataqalis history was recorded as evidence in the Native Lands Commission books where mataqali membership was likewise registered; native lands were surveyed and allocated to local mataqali, and this model remains definitive to this day - presently $87.9 \%$ of Fiji's land area belongs to indigenous Fijian groups (Fiji Bureau of Statistics, 2011). The material foundations of indigenous land rights, therefore, hardly support the taukei vs. vulagi distinction any more. Hocart's Lauan informants attested as much already in the early $20^{\text {th }}$ century:

"The nobles of old had no land; they had only the authority (lewa); it is only since the Tongan rule [in the Lau group] and the Government that it extends to the soil. They could not take land; only the sister's son could bring land to the nobles; the elders of the landsmen $[\ldots]$ would decide to give land for their sister's son to plant in. The nobles used to refer to us landsmen. » (Hocart, 1929: 98)

But it was not just the material conditions of the Land-Sea division that changed. Over the course of translating a seemingly endless number of Native Laws, Regulations, Bills, Bulletins and Circulars, the Native Administration also adopted a practice of translating "native Fijian" as taukei (rather than kai Viti - "Fijian" - for example), applying a term that in the old order was reserved for the titular land owners in reference to the entire native population. I am not saying that this act of re-naming by itself would have necessarily changed anything, but combined with the communal system of land ownership, not to mention the pre-cession acts aimed at reducing the Tongan influence in Fijian politics (see e.g. Derrick, 2001 [1949]: 143; Seemann, 1862: 250-251), it is justified to say that the material and historical conditions underlying Fijian chieftainship changed dramatically.

And of course the very same colonial administrators who took it upon themselves to finalise and codify Fijian culture also brought to Fiji a significant number of new "guests" - or was it "strangers" - the Indo-Fijian population that today makes up over $37 \%$ of Fiji's total population (Fiji Facts and Figures, 2011). Over the course of the history outlined above, they have repeatedly been deployed as the silent other against whom indigenous Fijian culture has been compared. As Kaplan and Kelly (2001) have shown, Indo-Fijians have been presented as business-oriented and lacking a culture of their own, whilst the rationale of bringing indentured labour into the islands in the late $19^{\text {th }}$ century was inseparable from the protectivist stance that the colonial administration adopted towards the indigenous population (see also Kelly, 2004). The deployment of racial stereotypes plays a significant part in the turn from xenophilia even to its opposite, xenophobia, as has become apparent at least during the 1987 and 2000 coups.

It should be emphasised that this is not a sudden change but rather represents a series of gradual, interrelated processes that have been unfolding for almost one and a half centuries. What I want 
to draw attention to here is that the subsequent shift in the connotations of guesthood and alterity represents a transformation of the conditions underlying chiefship particularly in eastern Fiji. After all, the ability of Fijian chiefs to encompass the social totalities of people that they rule over, it has repeatedly been emphasised in the literature (e.g. Hocart, 1970; Sahlins, $1985,1994)$, is grounded in their capacity to personify shared notions of power and charisma. The actualisation of these conditions is a far more complex issue to look into than simply laying out the structural argument. Moreover, it is something that cannot be conclusively argued with reference to a single locality in Fiji. What I want to do, however, is to portray one instance where a strong case can be made for precisely such a value shift. If this may happen in one particular place in Fiji, it may then be asked, the possibility of parallel developments ought to be looked into elsewhere as well.

\section{The case of Naloto, Verata}

Naloto is the largest of the seven villages that make up the land (vanua) of Verata ( $c f$. Eräsaari, 2013: 16). The village is home to roughly 300 people, in addition to whom there are more than twice as many people registered in the Native Land Register as Nalotans but who do not live there. Less than a mile from the village of Ucunivanua, home of the Verata paramount chief, Nalotans take great pride in being part of the chiefdom of Verata: the kin groups in the village trace their histories back to the mythical founding of the kingdom in Verata (see below), whilst in historical times, Naloto was the stronghold of the Veratans during the Cakobau wars when Ucunivanua was burnt to the ground. Together with the villages of Kumi, Sawa and Uliloli, Naloto is classified as part of the Yavusa Qalibure, or the Verata high chief's land warriors. Naloto is thus a commoner village of relatively low status within the chiefdom, though representative of Verata's high chiefly status when Nalotans visit another chiefdom. The village itself divides into two local-level yavusa or moieties, land and sea. The groups comprising the land moiety own $94 \%$ of the village lands and the head of the land moiety, the Komai Naloto, is the hereditary village leader. On ceremonial occasions, he represents the entire village; encompasses both moieties, even though the sea moiety has its own chief, titled $\mathrm{Na}$ Tunidau.

The sea moiety, for their part, are descendants of a chiefly lineage from Ucunivanua; they are "nobles", turaga, as a land moiety man once pointed out to me, and genealogically outrank their village neighbours. At the same time, a sea moiety elder once pointed out, "the kai wai are not supposed to be in Naloto" but represent a division which, in his opinion, should only exist in a chiefly village. With this he meant that the presence of sea people in a non-chiefly village represents a departure from the established order of things. However, this would be a highly typical anomaly insofar as there are in fact sea people in at least six out of the seven Verata villages. Hence, in Hocart's terms, the sea people are regularly occurring strangers who "do not belong to the original scheme of things". Yet they, too, call themselves taukei, regarding themselves both "the original and native settlers of Fiji" and land owners in Naloto.

At the very beginning of my 2007-2008 fieldwork in Naloto, one of my hosts - a sea moiety man just a few years my senior - explained me: "We have always been here, we were the first! The originals [laughs], the originals." "What about the people on the other side", I asked, meaning the other half of the village associated with the land moiety, "where do they come from?" "Everyone was always here", my friend explained and repeated. "We are the originals, we have always been here".

At that time, what struck me as odd was that he had just finished explaining to me a version of the widespread origin myth according to which all Fijians originate from Tanganyika, Africa. Different versions of this myth are widely accepted throughout Fiji; I have heard the same core myth, with only minor variations, recounted from the Mamanucas to Tailevu, and have good reason to believe it is accepted further east as well. A key feature of the myth lies in its ability to provide a shared history for all indigenous Fijians. In a Naloto version, for example, "the first Fijian taukei" set out from Tanganyika, crossed the seas with canoes that were expertly handled by their "sea people", until they reached Vuda on the west coast of Viti Levu. Some versions say they then split up in Vuda: the land people crossed the island on foot through the interior; the sea people took the canoes round the island. Finally they all settled in Verata on the east coast, where their leader, the mythical hero Rokomoutu, founded the first kingdom of Fiji.

As Kaplan (1995: 28) points out, the myth could just as well stand for foreign origin in contrast to fully autochthonous origin myths (e.g. Tregear, 1903 ) in which the "original" Fijians are created in Fiji, from the local soil or fauna. But this is not the use to which the myths are put to in Naloto, as evident already from the citation above. Rather, the origin stories portray the arriving Fijians as first settlers, whether that be in Fiji in general or in a particular locality - or both, as in Verata. Hence in Naloto village, the same pattern is repeated 
in every local group's origin story: each group in the village - typically classified as mataqali (see Eräsaari, 2013: 22-31) - has its own origin story, and all of them emphasise the group's "originality" in the village. The group said to have originated from the inland polity of Naloto and thence given the village its name, I was once explained, are "the same Naloto as those in Naitaisiri, but they have always been here". It is similar with the other clans in the village: one claims to have occupied land adjacent to the present-day village before the arrival of the others, another to have been the first but then conceding the chieftainship to another group, and so forth. And since Nalotans as a rule do not find it necessary to contest each others' accounts, every group is equally original to the place, every group was the first. Even the sea people in Naloto make the same claim, despite the fact that they are latecomers in the village: they moved to Naloto from the neighbouring village in the early $20^{\text {th }}$ century. They, however, claim originality by being originals to the chiefdom of Verata rather than the village of Naloto: it was their founding ancestor, the sea chief Ramasi, who oversaw the migration from Africa. But as evidenced by the Naloto sea people's story of their arrival in Verata, power is thought to always have been on the "land" side:

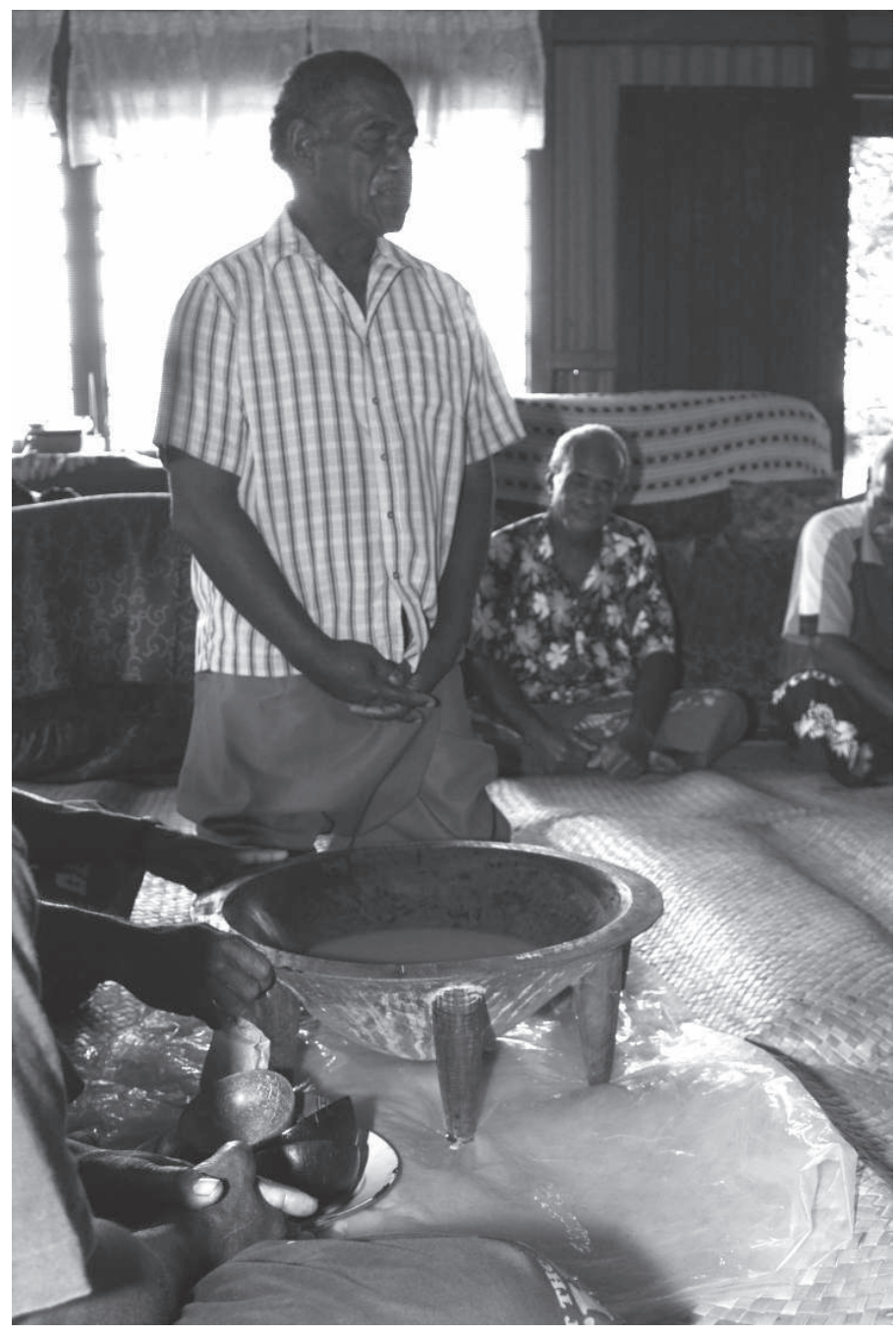

PiCture 1. Tanoa - inside water, outside land, Naloto village, 2008 (photograph by Milla Eräsaari)

"when they arrived at Verata, Rokomoutu asked Ramasi if they could have a bowl of yaqona to thank him for sailing them safely through the rough oceans. So they prepared the yaqona, but there was no cup. So Rokomoutu asked Ramasi: 'you drink first, because you're older than me'. Ramasi replied: 'No, I cannot drink it, you drink the yaqona first.' But Rokomoutu insisted: 'Oh, this is just to express our thanks to you for protecting us from the high seas.'

They kept on arguing like that, until finally Ramasi bent over to drink the yaqona inside the tanoa without using a cup. While he was doing that, Rokomoutu knew our land, Verata, will be lead and looked after by these kai wai people. 'This is not good', he thought, and so he pressed Ramasi's head right in to the tanoa.

Ramasi cleaned his face with his hand and said: 'What have you done? This is shameful, you shouldn't have done this. You asked me, I told you to drink first but you told me to drink first. But when I was drinking, you pressed my head down. Why? Rokomoutu didn't say anything. He was ashamed. And so Ramasi told Rokomoutu: 'From now on, we'll share this $t a-$ noa. Inside it's water; outside it's land. I will look after the sea, you look after the land. Whatever is found in the sea is mine; islands and everything out of the sea, out of Verata is mine. Yours will be the land round here. » (Abbreviated from an English-language narration by a sea moiety clan elder recorded in July 2007)

The myth reveals the Naloto sea people's preference for classifying themselves amongst "the original and native settlers of Fiji": the sea denomination is primarily regarded as a hereditary occupational proficiency, so that sea people (kai wai) are assumed to be expert fishermen and sailors. Yet they share a common origin, common substance, with all the other taukei in Fiji. But there is more to the myth, obviously. It also shows that just like the sea people were skilled professionals from the very beginning, so the ruling chiefs were landsmen. In this particular myth, the narrator goes as far as to bend the Viti Levu geography to match the shift in relations of encompassment, making land contain the sea like a kava bowl contains the liquid inside it (picture 1). 

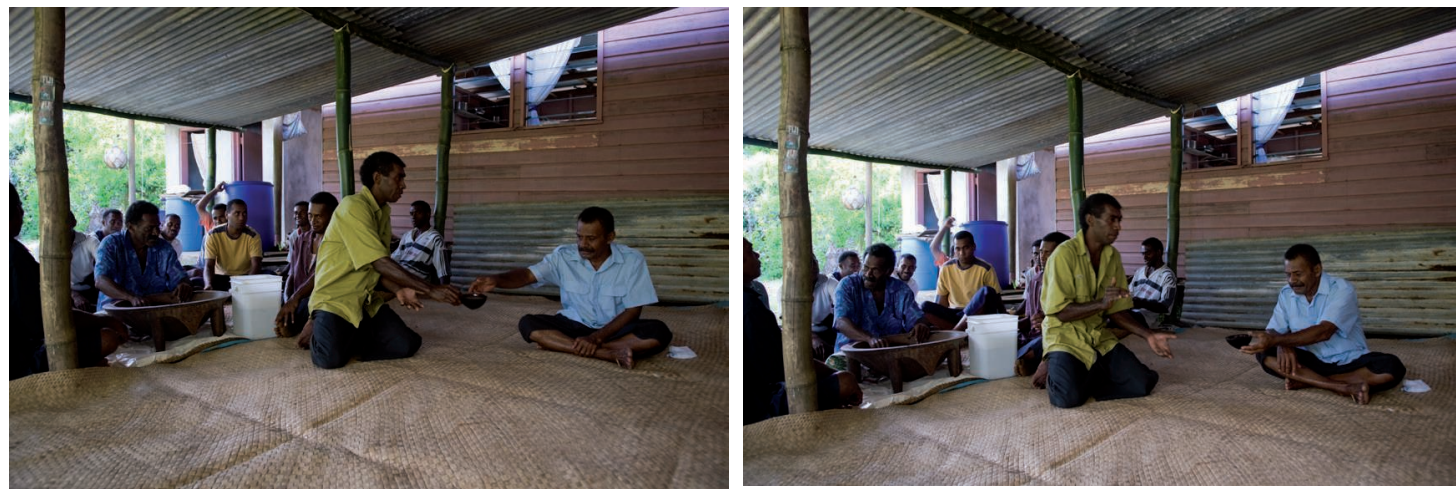

Pictures 2-3. - A man of the chiefly clan receiving the first cup during a funeral, Naisausau village, Namara, 2008 (photograph by Milla Eräsaari)

The ascendency of the land affiliation, furthermore, coincides with what can be described almost as the disappearance of "sea" goods from traditional exchanges. Instead of the prescribed exchanges in pigs and fish described above, the villagers and their Tailevu neighbours now prefer exchanges in mutually similar substances - taro, cassava and beef. Pigs, the land people's ceremonial offering, are still at times used to mark out particular personages, but fish has become a seldom-used ceremonial gift. The generally preferred ceremonial meat item (sasalu) is now beef, which for example in funeral rites is typically accompanied by root crops, pandanus mats, yaqona and whale teeth, and eventually reciprocated in kind.

The whale teeth, while remaining in use, have been thoroughly "indigenised". In the locally best-known myth accounting for their origin, the first tabua was made by Rokomoutu's disowned son, Buatawatawa, from a branch $(t a b a)$ of the Frangipani (bua) tree on the island of Vanua Levu in Fiji. The autochthonous wooden objects were, according to this story (for a longer version, see Eräsaari, 2013: 133-134) replaced by whale teeth only when European whalers made their way to Fiji in the $19^{\text {th }}$ century. Indeed, a whale tooth is now sometimes known as a tabua ni Viti-a "Fijian tabua" - though to distinguish a "Fijian" whale tooth from what, that I do not know. Perhaps from the "tabua lasulasu", counterfeit whale teeth made out of plastic: objects which, so the villagers assured me, are made by "some people in Australia", by "Indians" or simply by generic "foreigners" - anyone but the taukei, that is. Hence a genuine whale tooth is now considered autochthonous to Fiji whilst the counterfeit item is considered foreign.

The distinctive value of foreign origin has, in other words, not just fallen out of favour in Naloto; it has taken on a markedly negative connotation. But along with it has gone the passion for difference itself, previously exemplified in the chiefs, groups and the exchanges they made. Instead of the exchanges in pigs and fish described by Hocart (1924, see above), Nalotans now prefer mortuary gifts (reguregu) comprising tabua, mats, oxen, taro and cassava: compiled prestations that stand for men and women, land and sea alike, and tend to be reciprocated with more of the same over time. They generally reciprocate ceremonial gifts of yaqona (sevusevu) with more yaqona, and always, always respond to a tabua received with another tabua (for full details, see Eräsaari, 2013: 124-186).

Steven Hooper (2013), drawing on material collected in the Lau group, explicitly states that presenting whale teeth in combination with other categories of exchange items - such as feast food (magiti) - and the undiscriminating reciprocation of tabua with tabua, regardless of context, would both go against received protocol (Hooper, 2013: 122, 129). Hooper exemplifies the latter with a Kabara informant's account of atoning for an elopement (bulubulu), a context wherein a tabua should not be reciprocated (though this obviously can happen in Lau, too). Nalotans, for their part, not only systematically reciprocate whale teeth given as bulubulu, they also systematically combine the bulubulu with another ritual event, the kau mata ni gone, in which a child is presented to his/her maternal relatives. Both of these are quintessentially events in which the two parties or "sides" are not of equal standing: the bulubulu is an event for humbly asking for forgiveness, the kau mata ni gone an ostentatious affair for asserting a child's vasu rights which, as one of Simonne Pauwels' Lauan informants puts it, "should not be an exchange, otherwise we become equal again" (Pauwels, 2015: 151).

In Naloto, the two terms - bulubulu and kau mata ni gone - both refer to the prototypical Naloto wedding that is organised once the couple have a child that they can present to the girl's family. The choice of term used in reference to the event may still depend on whether the speaker is of the boy's or the girl's group: the former would be more likely to call the event a "kau mata ni gone", the latter could call it a "bulubulu" - whilst 
the couple at the centre of the ritual would be likely to label it vakamau: a "wedding". Yet the content of the ceremony remains the same: the wedding comprises two recognisable parts or rites that are always performed in succession. The first is the bulubulu, atonement ("burying" of the ill deed). In the bulubulu the boy's side the guests (vulagi) - present tabua, print cloth and kerosene to the girl's side - the hosts (taukei) - to make up for "stealing" a bride (and receive an equal number of tabua in reciprocation). This was explained to me as a one-sided affair inasmuch as the hosts are the wronged party who are under no obligation to even receive the visitors, let alone their gifts. I was explicitly told that no feasting ought to be expected after what is, in the final analysis, a mere presentation of wealth given in recompense of a priceless human being. In practice, however, the bulubulu is always followed by another rite, the kau mata ni gone ("carrying the face of the child"), in which the child of the couple is presented to his or her maternal relatives. The linkage appears to be so well established, that I have even seen the marriage of a couple who had to wait long years because they had no child to present. In the end they held the ceremony after adopting a child from a close relative. In the kau mata ni gone, the child, carrying a tabua, is presented to a maternal grandmother: they exchange tabua, whilst the ceremonial wealth brought by the visitors (more cloth and kerosene, though these gifts are often collated into the presentation made during the bulubulu) is reciprocated with the thick pile of pandanus mats and tapa that the grandmother was waiting upon. A feast offered by the hosts in honour of the guests concludes the event. The label adopted obviously does affect the way one morally evaluates the situation: a group that arrives to bulubulu are wrongdoers who should not expect anything in reciprocation, a group arriving to kau mata ni gone will be the honoured guests of a feast. The ritual, nonetheless, always follows the same format, in which every tabua is reciprocated with a tabua and a feast is given after the gift exchanges. By fusing the two into a single ritual, Nalotans display their preference to render practices that are elsewhere markedly unequal into displays of balanced reciprocity, bordering on competitive equality (McDowell, 1990; Toren, 2000; Eräsaari, 2013).

Christina Toren $(1994,2000)$ has referred to the Fijian ideologies of hierarchy and competitive equality - overlapping the "sea" and "land" denominations - as an "antithetical duality", pointing out that the two should be regarded as aspects of one another (Toren, 2000: 226). They constitute a single idea, an opposition upon which much of Fijian social life and political organisation is based, as evidenced in the "election" and installation of Fijian chiefs.
It would actually be impossible, she points out, for chieftaincy to be based on an all-embracing hierarchy any more than it is possible to maintain chieftaincy on the basis of equality; "in Fiji, equal and hierarchical relations invariably implicate one another - so much so that at times they threaten to collapse into one another, and the challenge is to keep them distinct" (Toren, 2000: 119).

Looking at the semantic value accruing to the land and sea denominations - their mythological denotata, if you will - one could justifiably argue that in Naloto, the two have indeed "collapsed into one another". The "stranger" or "foreigner" is a prime example of a category which can only be upheld in a dichotomous relation to its antithesis; without the stranger, the in-group also lacks a definition, as Lévi-Strauss' (1952, 1970) work also makes clear. This contrast is absent from the myths considered relevant in Naloto, where everyone are simply "originals".

The corresponding absence of chiefly elections or installations in Naloto fits the pattern almost too neatly. The last chiefly installation in Naloto took place sometime in the fifties or early sixties, and since then the village chiefs have been titled komai rather than ratu, the latter being the title born by the installed Naloto chiefs of old. I was told that this corresponds to diminishing status: that in comparison to the ratus of old, the current village paramounts are "just komais". The komai title, which according to Capell's Dictionary (2003 [1941]) is a short form for koya mai ("the one from..."), is used for the chiefs of every Veratan village except for the paramount chief in Ucunivanua, the Ratu mai Verata. The last Ratu of Naloto, so I have been told, was buried within the village perimeters with full ritual observances; since then the Komai Naloto have been buried in their mataqali's graveyard outside the village proper. A senior member of the kin group traditionally responsible for burying the chiefs suspects the installations ceased because the installing clan lost the paraphernalia required for installations. A senior member of the installing clan insists that the installations ceased when the chiefly group started picking out the chiefs by themselves, thereby violating the installers' right to elect the chief.

But this unilaterally transmitted title is not a particularly coveted one. Before the current komai, all senior members of the chiefly group refused the title in turn, so that it was handed to another lineage for a time, whilst several senior men also report that they refused the title before it was handed to its current holder. Nor is it a strong title. The villagers treat their hereditary chief with little respect: they disobey his commands, fail to consult him before initiating communal projects, talk while he is talking, many even make witchcraft accusations behind his back. The komai has no right to request 
people to work for him, nor does he receive any formal first fruits offerings - though people are generally uncertain whether even a Ratu Naloto ever received first fruits.

The komai, for his part, often fails to attend to his chiefly duties: he generally refuses the chiefly seat in the Methodist church, and is regularly absent from big ceremonial events, too - often because he was not consulted in advance. This is, by and large, no big deal: in his absence either the chief of the sea people (na Tunidau) or another member of the komai's mataqali assumes his place as well as his title.

This is the only model for village chieftaincy available to the villagers. No-one remembers what the installations were like, no-one knows how to perform them, and not once during my fieldwork in 2007-2008 did I hear anyone suggest re-instituting the practice. Neither did people ever discuss the possibility of making their Komai into a Ratu again. Yet this is not to say that they cannot show respect in the traditional mode. Take, for instance, the two formal chiefly funerals that occurred in Tailevu in 2015: those of the Verata paramount (Ratu mai Verata) and the Vugalei paramount (Vunisalevu na Turaga na Tui Vugalei). The latter, recognised as a chief of Verata's warrior allies, bati balavu, passed away in March 2015. His funeral was attended by a group of Naloto sea people, who joined the hosting group in the capacity of in-laws. On the occasion of this big, formal funeral organised by people known for their "traditionalism", the Nalotans did mark the event by presenting the traditionally prescribed fish in addition to gifts of tabua, yaqona, mats, biscuits, bread and the like. Upon the funeral of the Verata paramount in June 2015, Naloto attended the funeral together with the Sawa and Uliloli villages, presenting a pig in addition to tabua, yaqona, mats and taro and, furthermore, staying overnight in the chiefly village as a high chief's land warriors are supposed to.

However, recognising chiefship elsewhere and acting upon it in the custom-prescribed way has no bearing on issues of leadership closer to home. The fact remains that the relevant modes for articulating differentiation are absent in the community. Indeed, during my fieldwork I witnessed several occasions where recognition of the land-sea dichotomy was called for, such as several non-chiefly funerals in Vugalei, during which Nalotans went to considerable lengths to not take their traditional due. On one occasion, when a mataqali meeting admitted - at the insistence of a Vugalei lady married to Naloto - that a "sea" presentation was called for, the elders still decided to request money from an urban relative in order to buy a bull instead. On another, one of the sea moiety fishermen went through considerable trouble to catch an early-morning lorry to town in order to sell a big fish and use the money to buy taro for another funeral in Vugalei. And the same was even more pronounced within the village, where the local bati were at times angrily calling for the sea people to bring them fish that they could reciprocate with a "bati ni ika" - tabua presented in reciprocation for fish, but to no avail. Such differentiating features, it would appear, are only reserved for chiefs seen to preside over others, differentiated by distance. Thus it is in the chiefly village of Ucunivanua, too. Not even the Verata paramount was awarded full honours in his lifetime: I was always told that his own village was split over the paramountcy and he himself remained uninstalled. Indeed, the emphatic comments of one of his clansmen during his funeral seem to indicate as much: "He said only those from the Sobasoba clan knew who could become the titleholder [and added that] Ratu Ilisoni Qio was the next in line, the younger brother of the late Ratu" (Bolatiki, 2015).

And yet Naloto villagers would prefer to have a strong leader: they talk of the deeds of oldtime chiefs, look at the fine figures of ancient chiefs in the Fiji Museum photographs, talk of the deeds of the ancients. Many maintain that the title is simply held by the wrong man, that the rightful heir lives on another island or has refused the title. But it is just as common that they find fault with the village population at large. I was often told that the real problem is that "everyone wants to be chiefs", "everyone wants to be grand", or what amounts to the same, that "everyone wants to drink first" in the yaqona ring. There is a wide consensus about the fact that the chieftaincy is not as it ought to be, but the problem is conceived to be either at the top of the pyramid or at the bottom, or not irregularly both. There is, in other words, no prevailing view regarding the root causes of this conceived lack of leadership.

"The old ones", one of my friends once commented the absence of leadership in the village, "those who should be making the decisions do not know how to act properly [...] do not know how to give orders or to call people together". He thought that they only "stay up too late and wake up too late", a reference to excessive yaqona drinking. Yet he did not think that the solution to the problem was to be found in the elders' actions as such, or even in changing the chief. Instead, he saw it as a question of returning to the old ways: the villagers should invite "someone from Fijian Affairs" (now the Ministry of iTaukei Affairs) to teach them how to again observe the old food taboos. In his view, in other words, the route to rediscovering proper leadership lay in the rediscovery of differential roles in the village. Once the land and the sea sides would resume the food prohibitions that 
are the sign of their contrasting roles, the rest would follow suit.

This was as close as any of my interlocutors came to connecting the village-level issues with the long-term changes discussed in this article: an unspecified assumption that if villagers were again to start observing the discontinued food exchanges and corresponding prohibitions, chieftaincy would follow suit. As a rule, though, the villagers had no shared stance on the issue of chieftainship: some preferred to blame the bad food - biscuits and noodles - that make men less imposing than their forefathers, others blamed "human rights and democracy", whilst money was perhaps the most common scapegoat. What was common to these and many other explanations was that whilst they were not very specific on the causation, they all agreed that there was something amiss with leadership that was in need of fixing.

With regard to Fijian ethnography in general, this is a claim that has been heard before, whilst causes have been sought from diverse sources ranging from the mismatch between chiefly obligations and privileges (Sahlins, $1962)$ to increased commodification of interhousehold relations (Toren, 2007) or the effect of Christianity on the chiefs' mana (Tomlinson, 2009). My version, focusing on a shift in the valuation of origin, would probably be best taken as an addition to the existing literature rather than a challenge upon it. It is, nevertheless, the explanation that best agrees with the situation in Naloto, Verata, where the discourse is particularly preoccupied with origins. Not only does Nalotan mythology show a single-minded preference for local origin, the same occurs with whale teeth as well. This further corresponds with a shift away from the use of salt-water produce in ceremonial exchange, a media traditionally associated with guesthood vis-à-vis land ownership. Indeed, the points connecting village ideology with the state and colonial discourse are evident in the local connotations of the concepts for guest - vulagiand host - taukei.

During my fieldwork in 2008, many of my friends in Naloto recalled the heated racist anger towards the Indo-Fijian population that gripped Naloto, like many other northern Tailevu villages, during the 2000 coup. One can still hear the racial stereotypes of the greedy, calculating and profiteering "Indian" employed in village discourse. And even though the villagers are, by their own admission, now much more reflexive about issues of race and nationality, most nevertheless emphasise the notion that as taukei - meaning indigenous Fijians - they hold an inalienable claim on Fijian soil, one which all "guests" in Fiji ought to recognise. (For similar views, see Trnka 2008: 3.) However, this emphasis on hostship carries moral value that extends beyond questions of ethnicity - questions that are hardly part of everyday conversation in an all-indigenous village. In-marrying women, for example, can be described as vulagi, particularly if they are new to the village (Cf. Nabobo-Baba 2006: 45); likewise, I have heard visiting urban relatives being likened to "guests" with the implication that they come to partake in the hospitalities rather than shoulder collective responsibilities. But the logic of guests and hosts also unfolds recurrently on ceremonial occasions.

This can be exemplified with funerals, the most numerous of the different traditional (vakavanua) rituals held in the village. During a funeral the kin group of the deceased, known as taukei ni mate, receive each group of guests (vulagi) in turn, one after the other. Upon presenting the funeral gifts known as reguregu the whale teeth and beef discussed above - the guests proceed to take their place as part of the growing group of hosts gathered to welcome the next arrivals. In a large funeral, this can mean more than twenty arriving groups who, one by one, present their gifts and join the company of those who have come before them. In short, each group that arrives to a funeral goes from being funeral guests to being subsumed into the hosting group. The last group to arrive should be the weka ni mate, the group who bring the body and act as the ultimate guests in the funeral. It is upon their arrival that the expanded group of hosts moves to one side of the funeral space to face a small group of honoured guests. Once the two sides have completed a series of exchanges, these ultimate guests, too, become part of the funeral communion. The second day of the funeral brings this funeral communion markedly in focus: the church service and burial are followed by a feast and another formal yaqona session, at the end of which the guests of honour customarily ask permission to leave (tatau): once granted, the communion is considered over and others, too, are free to leave the funeral. This idea of unity is also emphasised in the exchanges: the activities leading to the reguregu put an emphasis on ceremonial pooling, conducted under the supervision of senior men, whilst the subsequent distribution of wealth is conducted unceremoniously by women. The traditional funeral hymn sang at every Fijian funeral service, "Meda sa tiko vakaveiwekani", expresses yet again the same idea of unity: "we are like kinsmen to each other".

What I want to draw attention to is this. The category of the host maintains a higher moral value, as is evident in the inter-ethnic application of the term, or the insecure status of a young wife in her husband's village: this has been noted before, for example by Norton (2000), NaboboBaba (2006) and Trnka (2008). But the ritual 


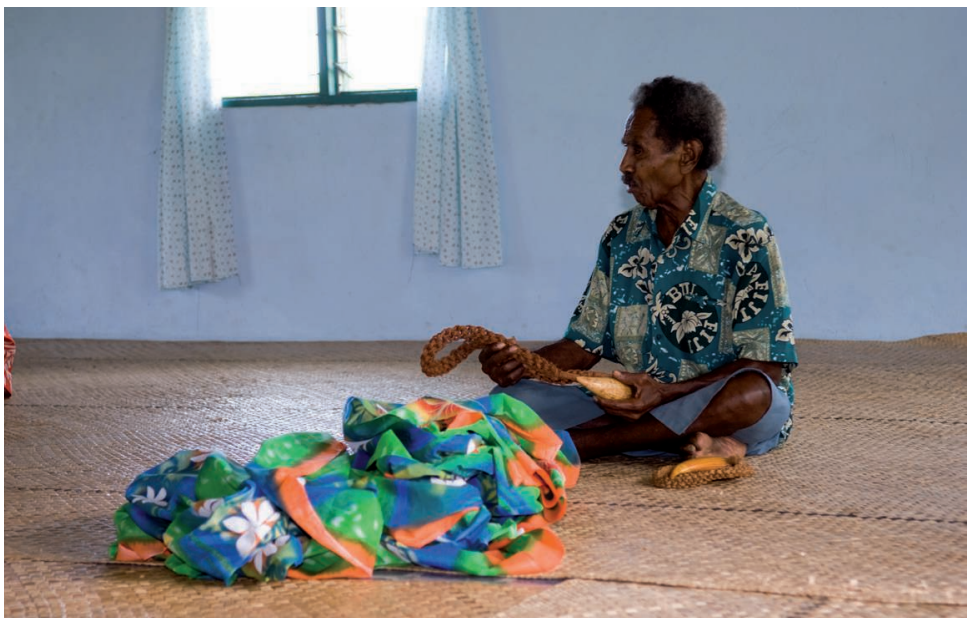

PiCture 4. - Na Tunidau, the head of the Naloto sea moiety, receiving ceremonial wealth during a wedding (Naloto village, 2007, photograph by Milla Eräsaari)

arrangement also presents a pattern in which the two sides are repeatedly merged into the hosting side. These events are overseen by and organised in terms of the hosts: they are an example of what Joel Robbins (2007: 297) has discussed in terms of "rationalisation", of the idea that in hierarchical arrangements

"valued elements tend to be more elaborately worked out $[\ldots]$ and to control the rationalization of less valued ideas. »

Hence the significance of the build-up to the valued moments, the combining of people and ceremonial wealth as well as the repetitive presentations that accompany the inclusion of individual groups to the ritual communion. In contrast, the moments of division and distribution are distinctively lacking in decorum and senior participation.

But following Robbins' idea of rationalisation, we can also view the entire movement away from stranger-kings, Tongan titles or foreign valuables (Sahlins, 1994) as an instantiation of the same value shift. Instead of foreign paraphernalia, we now find power in Verata wrapped in indigenous symbols - symbols which can, like the tabua, even remain precisely the same as before. But if we are simply talking about a reversal of polarities within a dichotomy, then why should it be of any consequence - "the more things change, the more they stay the same"? The answer is simple: strangers and alterity stand for a profound difference, in one way or the other they require the presence among "us" of something or someone whose origin lies outside the present society. The ideas of indigeneity or originality hardly require the presence of strangers among us, it suffices that they are somewhere out there. The problem with regard to political power is that such ideas offer a poor basis for distinction - it has to be found anew.

\section{Conclusions}

At least since the 1960s there has been a widespread consensus among the learned about the falsity of the myth concerning the African origins of the Fijian taukei (e.g. Sahlins, 1962; France, 1966): it is a recent, easily traceable construction and cannot be supported by archaeological or linguistic facts. By the time of my Ph.D. fieldwork in 2008, renouncing this myth had become such a routine act both in Fiji's classrooms and in popular newspapers like the Fiji Times and Fiji Sun, that people would often be ashamed of even talking about their beliefs regarding origins (see, however, Tuwere, 2002 for a more sympathetic view). All this myth-bashing has hidden in plain view what the myth actually stands for: the shared ancestry of all indigenous Fijians. To reiterate a view gleaned from a number of Tailevu villages, it makes no sense to talk about "autochthones" and "foreigners" if the entire indigenous population is thought to have arrived at the same time.

In this article I have argued, furthermore, that due to both colonial policies and $20^{\text {th }}$ century ethnic tensions, this merged identity has tended to emphasise the host/land owner side of the dichotomy rather than its opposite. The taukei concept, in its present-day form, could accommodate both autochthonous and foreign origin (insofar as both can be regarded the "original settlers" of Fiji) but the issue of land ownership tips the scales significantly in favour of the former. This is certainly so in the Veratan village of Naloto, where not just political power, but also the value invested in exchange items such as whale teeth is dressed in local rather than foreign clothes.

Steven Hooper (2013: 154) emphasises the latter point, stating that "[t]abua and chiefs may be regarded as equivalent, the former metonymically standing for the latter, and possibly vice-versa", while regarding both as "culturally constructed artefacts of external origin". But whereas Hooper's material from Lau is unequivocal about the external origin of both, my Naloto material sees them reversing polarities, while still maintaining "the explicit association, in testimony and in practice, between tabua and chiefs" (Hooper, 2013: 153). 


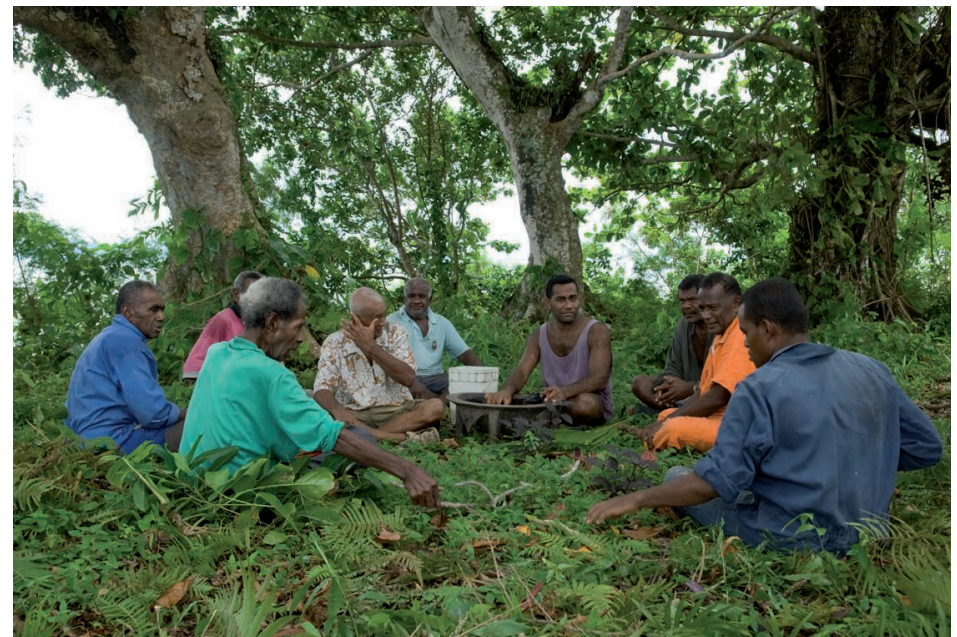

PiCTURe 5. - Drinking yaqona to mark the occasion of clearing up the chiefly burial ground where the old chiefs were buried (Naloto village, 2007, photograph by Milla Eräsaari)

But reversing polarities from a foreign to indigenous value - even moving across the invisible line separating xenophilia from xenophobia - implicates important structural changes for Fijian chieftainship. In practical terms, the changes described above do not allow for a select aristocracy to express their status and wealth as originality. Rather, the category of taukei now stands in opposition to other ethnic groups, exposing a shift from a structural arrangement where the value of alterity was expressed by groups of domesticated or "ingroup" strangers, to one where the negative value of alterity is - at least on the level of political organisation - moved outside the "us" group. From this point of view, the values crucial to the political organisation can no longer be evoked in an "among" relation but rather "between" increasingly clearly-demarcated groups.

Yet what applies for Naloto should not be generalised for all of Fiji, that much is evident just by recalling the Lauan examples discussed in this article, whilst much of the west of Fiji remains ethnographically uncharted territory. I therefore want to conclude this article by emphasising the fact that even the mythological foundation offered by the myth of African origins offers itself to other structural realisations besides the one discussed here. The most obvious is the one offered to Martha Kaplan (1995: 28) by a Vatukaloko man:

«I hold to Fiji only, I do not come from South America, Egypt, or Tanganyika. I have always been here, not arrived there. "

Іт is, in other words, still possible to insist upon the sea groups' alterity, whether they are keen to uphold such an idea themselves or not. Likewise, as I have tried to show, the land-sea dichotomy may be upheld without labelling either side as the foreigner, through an emphasis on their "occupational" roles, just as the host-guest relationship may also be relevant with regard to places of residence or temporary ceremonial roles. All of this does not, in other words, have to pose a "threat" to the dichotomous pattern within which matters of value tend to be articulated in Fiji: this structural arrangement itself ought to be considered a bearer of value rather than expression thereof. But what I believe has relevance beyond the village of Naloto or chiefdom of Verata, is the turn to "originality" adopted as a mode of legitimation, and this is something that I feel will only have an increasing influence on the way political authority is articulated in indigenous Fiji.

\section{Acknowledgements}

I would like to thank the editors and reviewers for the questions and comments that made it possible for me to present the argument in a readable form. The writing of this article was made possible by grants from the Finnish Cultural Foundation and the Emil Aaltonen Foundation to whom I am also grateful.

\section{BIBLIOGRAPHY}

Abramson Allen, 2013. A Locus of Exogenisation in Fiji. Traditions of Disjuncture and the Renunciation of Tradition in a Western Polynesian Context, Suomen Antropologi: Journal of the Finnish Anthropological Society 38 (2), pp. 4-22.

Arno Andrew, 2005. Cobo and Tabua in Fiji. Two Forms of Cultural Currency in an Economy of Sentiment, American Ethnologist 32 (1), pp. 46-62.

Bolatiki Maika, 2015. He Was Humble And Kind. Chief's Son. Fiji Sun Online, 4 July 2015 (available online at http://fijisun.com. fj/2015/06/04/he-was-humble-and-kindchiefs-son/\#share, accessed 10/09/2015).

Brewster A. B., 1922. The Hill Tribes of Fiji. A Record of Forty Years' Intimate Connection with the Tribes, London, Seeley, Service \& Co (available online at http://www.archive.org/ details/hilltribesoffiji00brew). 
Clunie Fergus, 2013. Tapua. "Polished Ivory Shrines" of Tongan Gods, Journal of the Polynesian Society 122 (2), pp. 161-210.

Derrick R.A., 2001 [1946]. A History of Fiji, Suva, Government Press.

Eкholm-Friedman Kajsa and Jonathan Friedman, 1995. Global Complexity and the Simplicity of Everyday Life, in Daniel Miller (ed.), Worlds Apart. Modernity through the Prism of the Local, London, Routledge, pp. 134-168.

ERSKINE John Elphinstone, 1967 [1853]. Journal of a Cruise among the Islands of the Western Pacific, London, Dawsons of Pall Mall.

EräsAari Matti, 2013. "We Are the Originals". A Study of Value in Fiji, Helsinki, University of Helsinki (available online at http://urn.fi/ URN:ISBN:978-952-10-9165-0).

Fiji Bureau of Statistics, 2011. Fiji Facts and Figures 2011 (available online at http://www. statsfiji.gov.fj).

Fison Lorimer, 1881. Land Tenure in Fiji, The Journal of the Anthropological Institute of Great Britain and Ireland 10, pp. 332-352.

France Peter, 1966. The Kaunitoni Migration. Notes on the Genesis of a Fijian Tradition, The Journal of Pacific History 1 (1), pp. 107-113.

—, 1969. The Charter of the Land. Custom and Colonization in Fiji, Melbourne, Oxford University Press.

Geertz Clifford, 1983. Centers, Kings, and Charisma. Reflections on the Symbolics of Power, in C. Geertz, Local Knowledge. Further Essays in Interpretive Anthropology, New York, Basic Books, pp. 121-146.

Godelier Maurice, 1999. The Enigma of the Gift, Chicago, University of Chicago Press.

Government of Fiji, 2010 (July 28). iTaukei Now Replaces "Fijian" and "Indigenous Fijian". Public Service Commission Circular No. 39/2010, File 29/685/23/2.

Hocart A. M., 1922. The Origin of Monotheism, Folklore 33 (3), pp. 282-293.

-, 1924. Maternal Relations in Melanesian Ritual, Man 24, pp. 185-186.

—, 1929. Lau Islands, Fiji, Honolulu, Hawaii, Bernice P. Bishop Museum (accessed via eHRAF World Cultures).

-, 1970 [1936]. Kings and Councillors. An Essay in the Comparative Anatomy of Human Society, Chicago and London, The University of Chicago Press.
Hooper Steven, 2013. "Supreme Among Our Valuables". Whale Teeth Tabua, Chiefship and Power in Eastern Fiji, Journal of the Polynesian Society 122 (2), pp. 161-210.

KAPLAN Martha, 1988. Land and Sea and the New White Men. A Reconsideration of the Fijian Tuka Movement, Ph.D. dissertation, Faculty of Social sciences, University of Chicago.

-, 1995. Neither Cargo nor Cult. Ritual Politics and the Colonial Imagination in Fiji, Durham, Duke University Press.

Kaplan Martha and John Kelly, 2001. Represented Communities. Fiji and World Decolonization, Chicago, University of Chicago Press.

Kelly John, 2004. Gordon Was No Amateur. Imperial Legal Strategies in the Colonization of Fiji, in Sally Engle Merry and Donald Brenneis (eds), Law \& Empire in the Pacific. Fiji and Hawaii, Santa Fe and Oxford, School of American Research Press and James Currey, pp. 61-100.

LÉvi-Strauss Claude, 1952. Race and History, Paris, UnESCO.

—, 1970 [1969]. The Elementary Structures of Kinship, London, Social Science Paperbacks.

Malinowski Bronislaw, 1984 [1922]. Argonauts of the Western Pacific. An Account of Native Enterprise and Adventure in the Archipelagoes of Melanesian New Guinea, London, Routledge.

Mauss Marcel, 1966. The Gift. Forms and Functions of Exchange in Archaic Societies, London, Cohen \& Cunnison.

McDowell Nancy, 1990. Competitive Equality in Melanesia. An Exploratory Essay, The Journal of the Polynesian Society 99 (2), pp. 179-204.

Nавово-BАва Unaisi, 2006. Knowing and Learning. An Indigenous Fijian Approach, Suva, University of the South Pacific, Institute of Pacific Studies.

Norton Robert, 2000. Reconciling Ethnicity and Nation. Contending Discourses in Fiji's Constitutional Reform, The Contemporary Pacific 12 (1), pp. 83-122.

Pauwels Simonne, 2015. The Vasu Position and the Sister's Mana. The Case of Lau, Fiji, in Christina Toren and Simonne Pauwels (eds), Living Kinship in the Pacific. Pacific Perspectives, New York \& Oxford, Berghahn, Studies of the European Society for Oceanists 4.

Ravuvu Asesela, 1991. The Facade of Democracy. Fijian Struggles for Political Control, 18301987, Suva, Reader Publishing House. 
Robiins Joel, 2007. Between Reproduction and Freedom. Morality, Value, and Radical Cultural Change, Ethnos 72 (3), pp. 293-314.

Rumsey Alan, 2000. Agency, Personhood and the "I" of Discourse in the Pacific and Beyond, Journal of the Royal Anthropological Institute 6 (1), pp. 101-115.

SaHLins Marshall, 1962. Moala. Culture and Nature on a Fijian Island, Ann Arbor, the University of Michigan Press.

—, 1972. Stone Age Economics, New York, Aldine de Gruyter.

—, 1983. Raw Women, Cooked Men, and Other "Great Things" of the Fiji Islands, in Paula Brown and Donald Tuzin (eds), The Ethnography of Cannibalism, Washington, Society for Psychological Anthropology, pp. 72-93.

-, 1985. Islands of History, Chicago \& London, University of Chicago Press.

-, 1994. The Discovery of the True Savage, in Donna Merwick (ed.), Dangerous Liaisons. Essays in Honour of Greg Dening, Melbourne, University of Melbourne, pp. 41-96.

-, 2012. Alterity and Autochthony. Austronesian Cosmographies of the Marvelous. Hau: Journal of Ethnographic Theory 2 (1), pp. 131-160.

-, 2013. On the Culture of Material Value and the Cosmography of Riches, Hau: Journal of Ethnographic Theory 3 (2), pp. 161-195.

SAussure Ferdinand de, 1993 [1983]. Course in General Linguistics, London, Duckworth.

Seemann Berthold, 1862. Viti. Account of a Government Mission to the Vitian or Fijian Islands in the Years 1860-61, Cambridge, Macmillan.

Stanmore Papers, ca 1875-1880. Fijian Legends and Traditions. Manuscript D-16, The Stanmore Papers (Papers collected by Lord Stanmore 1875-1880), Suva, Fiji Museum Archives.

Stasch Rupert, 2013 (22-24 April). Cultural Difference as Divine Monstrosity. Why Do Societies Think the Good by Thinking "the Other"?, Paper presented at the symposium "Toward a Comparative Study of the Good", Helsinki Collegium for Advanced Studies.
Thomas Nicholas, 1991. Entangled Objects. Exchange, Material Culture, and Colonialism in the Pacific, Cambridge, MA, Harvard University Press.

—, 1995. Exchange Systems, Political Dynamics, and Colonial Transformations in Nineteenth Century Oceania, in Peter Bellwood, James J. Fox and Darrell Tryon (eds), The Austronesians: Historical and Comparative Perspectives, Canberra, ANU Press, pp. 287-308.

Thompson E. P., 1970 [1963]. The Making of the English Working Class, London, Pelican Books.

Tomlinson Matt, 2009. In God's Image. The Metaculture of Fijian Christianity, Berkeley, Los Angeles and London, University of California Press.

Toren Christina, 1988. Making the Present, Revealing the Past. The Mutability and Continuity of Tradition as Process, Man New Series 23 (4), pp. 696-717.

—, 1994. All Things Go in Pairs, or the Sharks Will Bite. The Antithetical Nature of Fijian Chiefship, Oceania 64 (3), pp. 197-216.

—, 2000. Why Fijian Chiefs Have to Be Elected, in João de Pina Cabral and Antonia Pedroso de Lima (eds), Elites. Choice, Leadership and Succession, London, Berg, pp. 113-129.

-, 2007. Sunday Lunch in Fiji. Continuity and Transformation in Ideas of the Household. American Anthropologist 109 (2), pp. 285-295.

Tregear E., 1903. The Making and Un-Making of Man (a Legend of Fiji), The Journal of the Polynesian Society 12 (3), pp. 182-183.

Trnka, 2008. State of Suffering: Political Violence and Community Survival in Fiji, New York, Cornell University Press.

Tuwere Ilaitia S., 2002. Vanua. Towards a Fijian Theology of Place, Suva, Fiji, Institute of Pacific Studies, University of the South Pacific and Auckland, New Zealand, College of St John the Evangelist.

Williams Thomas, 1985 [1858]. Fiji and the Fijians, Vol. 1: The Islands and their Inhabitants, Suva, Fiji Museum. 